\title{
Water Regime and Flow Trends of Sitnica River
}

\author{
Arban Berisha
}

\section{ABSTRACT}

River Sitnica is one of the large rivers of Kosovo, which makes problems through its river basin, such as frequent floods and pollution. Especially if we add impact of climate change, then problems get worse. Among all, there is a lack of continuous hydrometrical observation. Those existing data are not complete, and not so confident. So, before any estimation of water regime, flow trends and identification of climate change, there is first to analyze flow data, to complete them with the known statistical methods. In this case, this problem has been solved by method of correlation with neighbourhood well-observed data. Just after data validation, there has been analyzed and shown its water regime, estimated flow trend, and is given correlation of temperatures, precipitations and flows for main gauging station. Correlation of these basic parameters has been extended for 21 years, where can be seen strong increasement of precipitation, certain increasement of temperatures and flows, as well as strong extremization of these parameters. At the end is given impact of convection rainfall, due to intensiv urbanization. These results should alarm competent authorities, on preventive action, to soft consequences, in next two decades.

Keywords: correlation, extremization, parameters, prediction, trend.
Published Online: July 08, 2021

ISSN: $2684-446 \mathrm{X}$

DOI : 10.24018 /ejgeo.2021.2.4.149

\section{Arban Berisha}

"H. Prishtina" University, Civil Engineering Faculty, Prishtina, Kosovo.

(e-mail: arban.berisha ${ }^{\circledR}$ uni-pr.edu)

\section{INTRODUCTION}

Sitnica River has the same destiny as other rivers of Kosovo, which are not hydrometrically observed continuously on long-term, having not complete and confident data, without which, could not be estimated main parameters of regime and hydrological trends, especially considering obviously climate changes. Rive Sitnica yields along Sar mountain ridge between Ferizaj (Urosevac) and Shtime (Stimlje) towns, then flowing to north, collecting on left and right side, streams of Gadime, Gracanica, Drenica, Pristina and Lap, up-to discharge on Ibri (Ibar) river at Mitrovica town. The best existing flow data of Sitnica river, on gauging station Nedakovac, nearby Mitrovica, are average daily flows, of years 1963-1985, accept years 1972 and 1979 [9], and years 1991-1998 [8]. After these years, there is not any flow continual and confident data. Therefore, without data completion, cannot be estimated any hydrometrical parameter, important for hydrotechnical problems solution.

\section{MATERIAL AND METHODOLOGY}

For data completion, was assumed the methodology of Correlation on regional similarity. There was chosen river Topljica at gauging station Doljevac, which is near to Sitnica river and is well observed. Those daily average flow data, can be downloaded on internet from Hydrometeorological Station of Republic of Serbia. After correlation of flow data of both rivers for existing years, the best result has been achieved for year 1965. The correlation coefficient for that year for 365 days results $96 \%$, and $98 \%$ without seven outliers. Down in the figure 3 , is given yearly hydrograph, of the year 1965, on format of logarithmic flows.

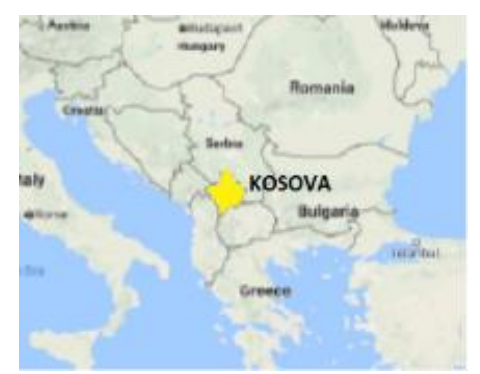

Fig. 1. Kosovo regional position.

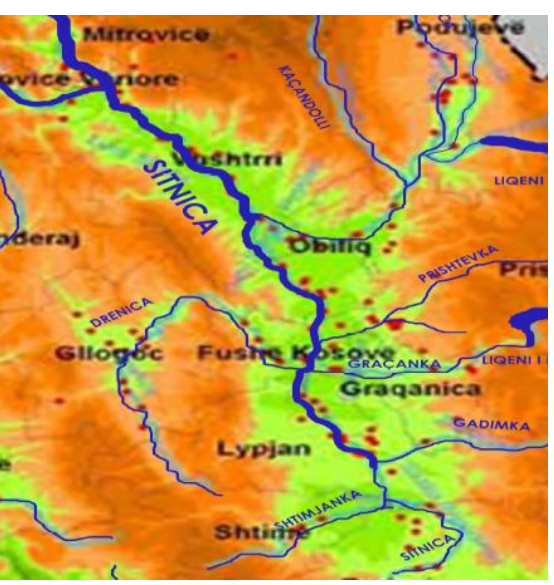

Fig. 2. Sitnica river basin 


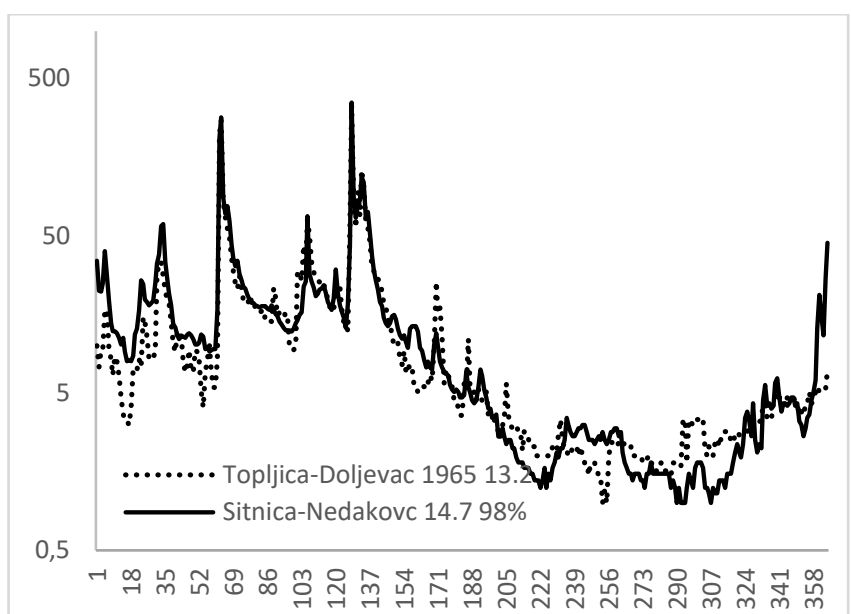

Fig. 3. Daily average flows Hydrographs of river Sitnica at Nedakovac and river Topljica at Doljevac, with the correlation coefficient $98 \%$.

Being that this is the biggest correlation coefficient, this year correlation parameters $a$ and $b$ were selected for generation of data of missing years. After data generation of missing years, there, has been tested correlation between observed data and generated data for year of 1997. The best coefficient of determination (Pearson) results $89 \%$. In the next figure, are given Hydrographs of daily average flows of observed and correlated (simulated) data for year 1997.

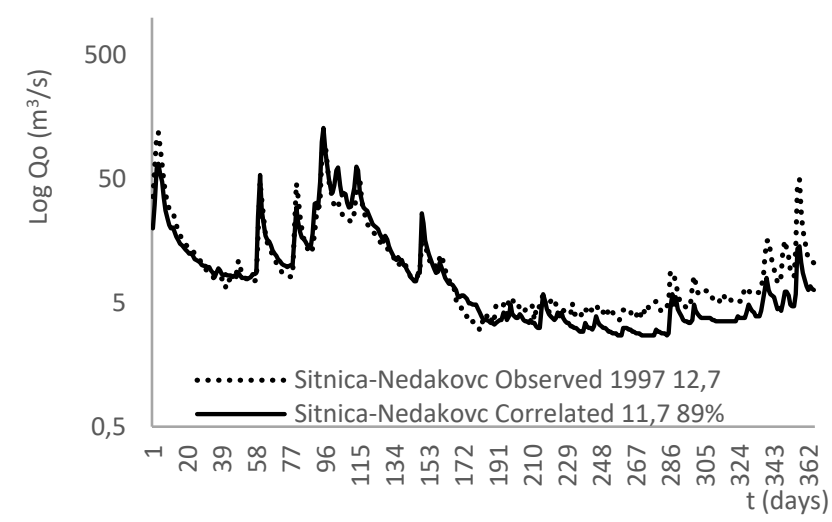

Fig. 4. Daily average flows hydrographs of year 1997 observed and correlated of Sitnica river at Nedakovac.

Testing has been done, by Nash-Sutcliffe coefficient, and it is as follows:

$$
R_{N S}^{2}=1-\frac{\sum\left(Q_{O B S}-Q_{C O R R}\right)^{2}}{\sum\left(Q_{O B S}-Q_{A V E, O B S}\right)^{2}} \text { for } \mathrm{i}=1-365
$$

where is:

$R_{N S}^{2}$ - fitting quality indicator of observed and correlated hydrographs according to Nash - Sutcliffe;

QoBs - observed flows;

QCORR - correlated flows;

$\mathrm{Q}_{\mathrm{AVE}}$ - average flow of observed flows.

In this case, the fitting quality indicator is $78 \%$, which is very well quality, comparing with no data at all. There are also other fitting indicators, which will determine fitting quality in higher scale, as fitting of averages, fitting of forms, fitting of dry and wet seasons [1].

Relative residuals for minimal, average and maximal flows are:

$$
\begin{gathered}
\mathrm{dQ}_{\mathrm{MIN}}=8 \% d Q_{i}=\frac{Q_{o b s-Q_{c o r}}}{Q_{o b s}} * 100(\%) \\
\mathrm{dQ}_{\mathrm{AVE}}=9 \% \\
\mathrm{dQ}_{\mathrm{MAX}}=-9 \%
\end{gathered}
$$

After completion of daily average flows, for time period from 1963 until 2016, in the next figure are given long-term monthly average flows. There are long-term average monthly flows hydrographs, for total period time of 1963-2016, and for two sequent time periods of 1963-1990 and 1990-2016. Winter months (traditionally with snow) are showing flow decreasing due to snow pack thickening. Last two decades in Aprille month, the flow is increasing due to precipitation increasing. During spring and summer season, the flow doesn't change (zero snowpack, les precipitation, typical continental flow regime). Further in autumn months, the flow is decreasing, last two decades, flows are decreasing due to precipitation decrease. This is rainy-snow regime of hillyfield catchment area, with one maximal flow during winterspring snow melting, and one minimum during summer, usually in August.

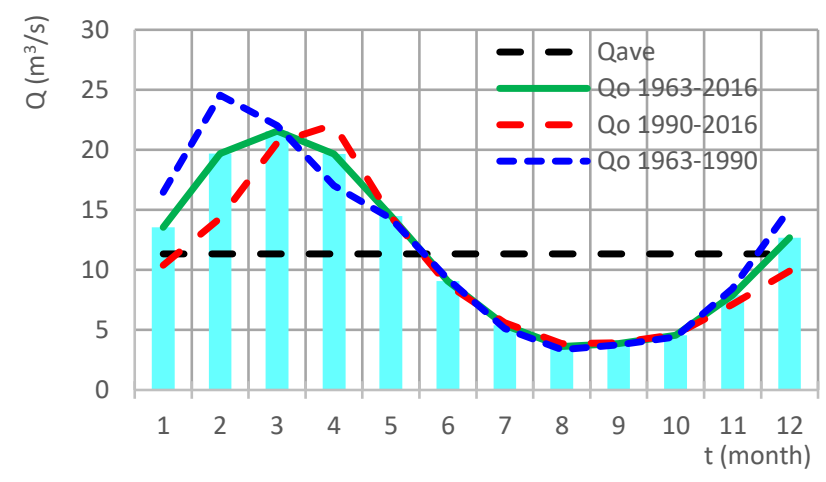

Fig. 5. Long-term hydrographs of monthly average flows, of SitnicaNedakovac.

In the Fig. 6, are given Long-term Hydrographs of annually average flows, of Sitnica river, and its trend for all characteristic: 1963-1990 and 1990-2016. Hydrograph of early time period is periodic with developed variances and flow, while last time period hydrograph is not periodic, showing increase of variances (oscillation) and increase of flow trend (due to precipitation increase). The total time period hydrograph is showing trend decrease of annually average flows.

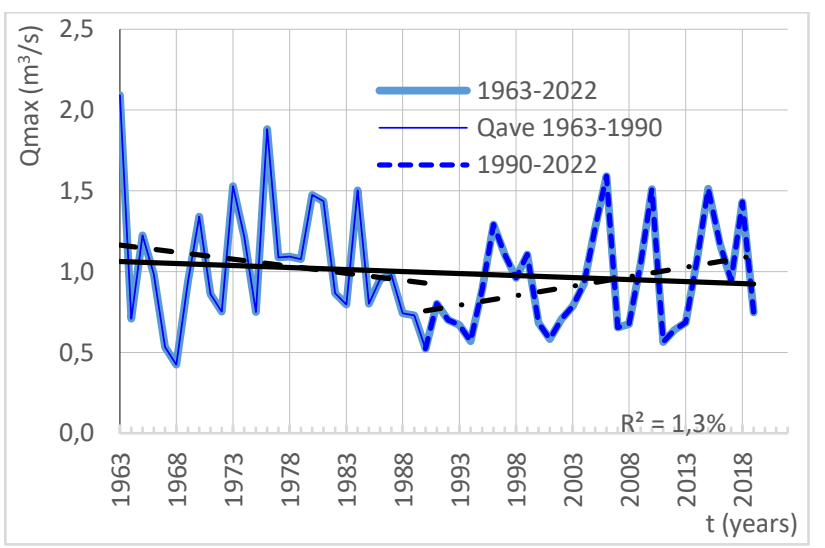

Fig. 6. Long-term hydrograph and its trends of annually average flows during three time periods of Sitnica river at Nedakovac gauging station. 
In contrary, are presented long-term hydrographs of average annual flows, of river Ibar at station Ribaric. This is a hydrograph of mountain river, which was not impacted by human activity and urbanism.

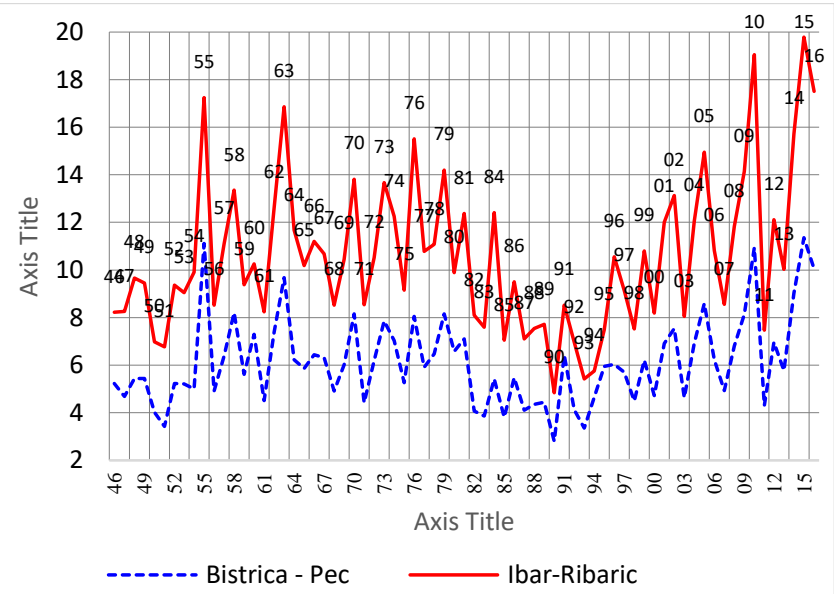

Fig. 7. Long-term hydrograph of average annual flows of river Ibar at Ribaric and Bistrica at Pec.

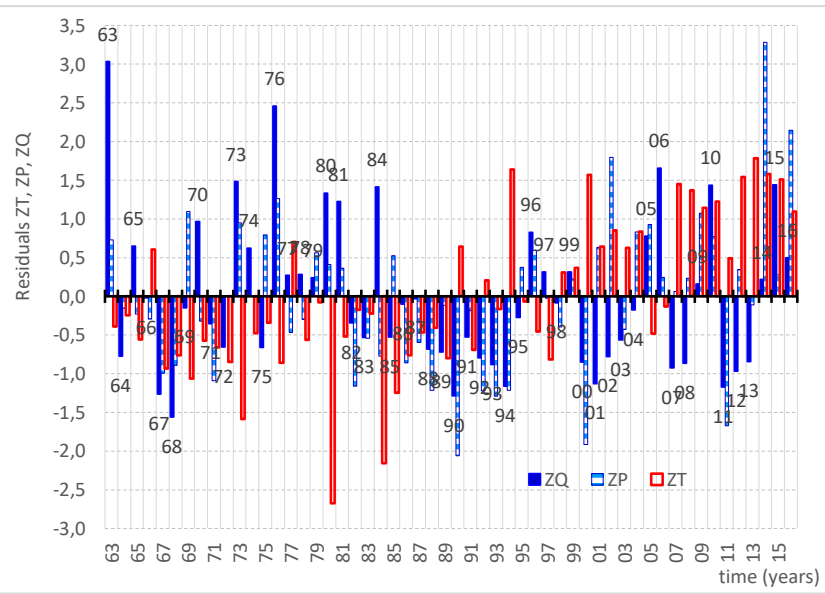

Fig. 8. Long-term relative residuals of temperatures $\mathrm{T}(\mathrm{OC})$, precipitations $\mathrm{P}(\mathrm{mm})$ and flows $\mathrm{Q}\left(\mathrm{m}^{3} / \mathrm{s}\right)$, for time period 1963-2016.

In Fig. 8, is presented histography of relative residuals of annual average temperatures, precipitations and flows of river Sitnica where can be well distinguished correlation and noncorrelation of these three hydrometeorological parameters:

a) Low temperatures with high precipitations and flows and

b) High temperatures with low precipitations and flows, during early periodic decades and during recent non-periodic decades.

There is also, in Fig. 10 given extrapolation and forecast of these hydro-meteorological parameters up to year 2040, and results are as follow:

a) Precipitation increasement up to $80 \%$ (with extremization)

b) Temperatures extremization up to $40 \%$ also with extremization and

c) Moderate extremization of average flows up to $20 \%$ (because of evaporation impact), also by extremization.

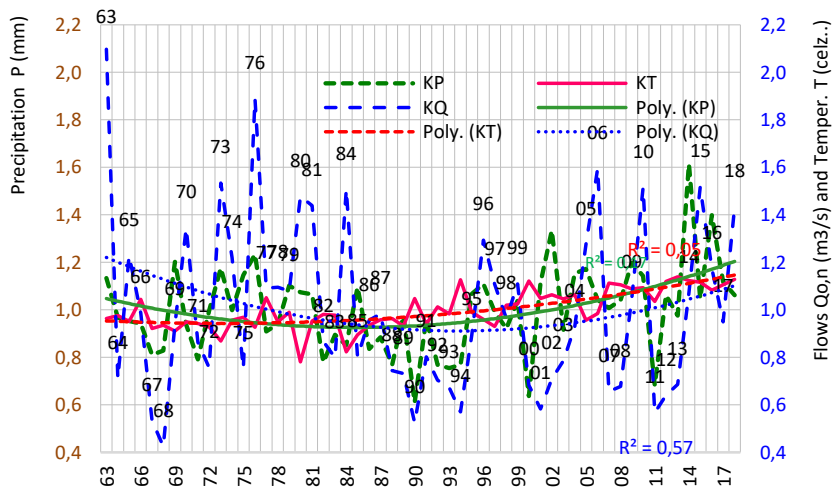

Time t (years)

Fig. 9. Long-term Hydrographs of residuals of temperatures $\mathrm{T}(\mathrm{OC})$, precipitations $\mathrm{P}(\mathrm{mm})$ and average flows $\mathrm{Q}\left(\mathrm{m}^{3} / \mathrm{s}\right)$ during time period 1963 2018

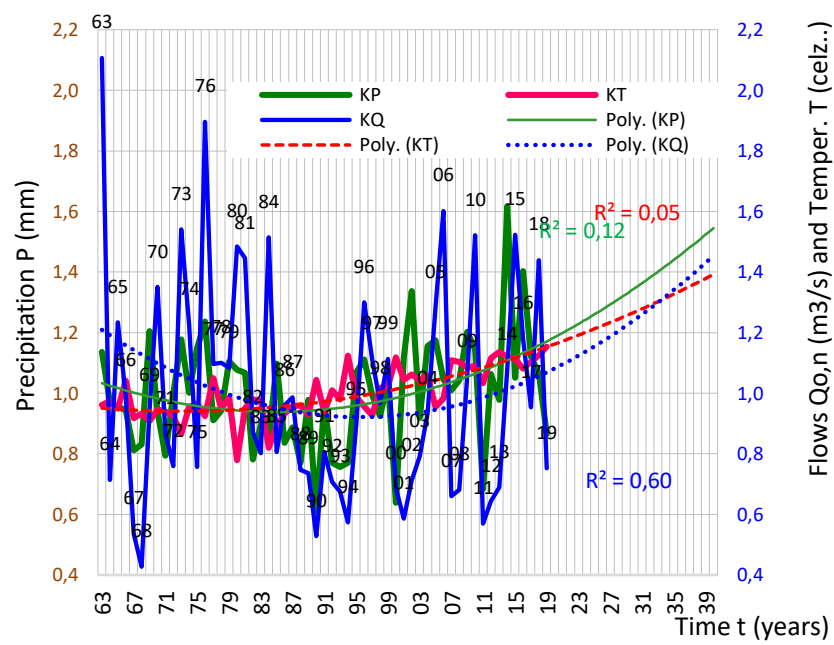

Fig. 10. Long-term Hydrographs and prediction until 2040 of relative values of temperatures $\mathrm{T}(\mathrm{OC})$, precipitations $\mathrm{P}(\mathrm{mm})$ and average flows $\mathrm{Q}\left(\mathrm{m}^{3} / \mathrm{s}\right)$ during time period 1963-2016.

Concerning probability of annual average flows, according to what has been sad before, and to Fig. 11, can be seen that flows are decreasing while time period of returning is increasing.

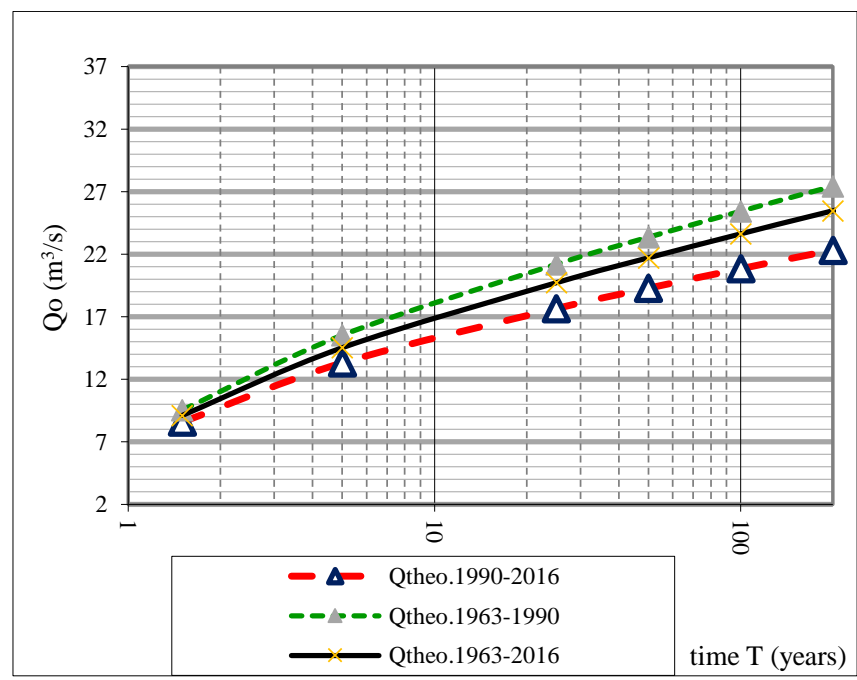

Fig. 11. Probability of annual average flows, after Log-Pearson, for three characteristic time periods of river Sitnica on gauging station Nedakovac.

Same change is appearing at the probability of high flows. As can be seen in Fig. 12, annual maximal flows are showing decrement of flows and increment of returning period (for 
same flows less probability).

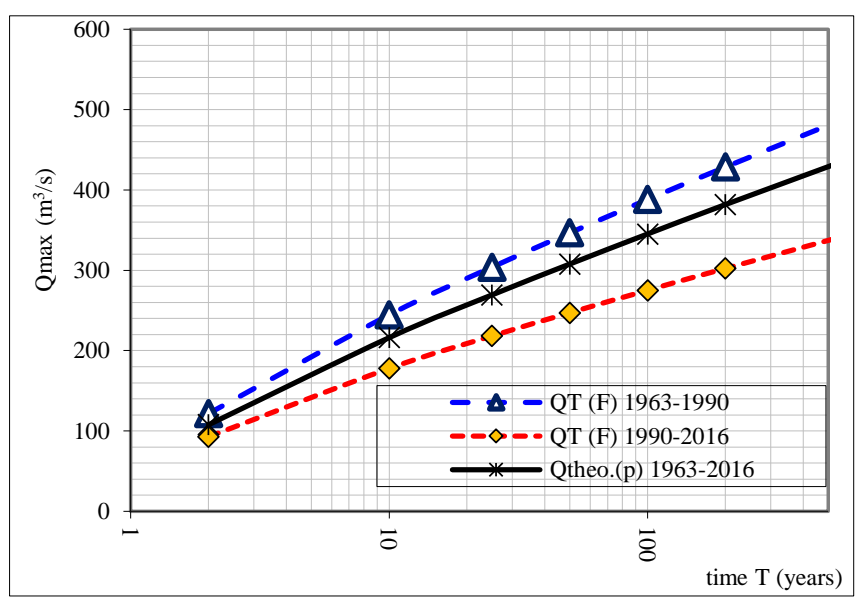

Fig. 12. Probability of annual maximal flows, after Log-Pearson, for three characteristic time periods of river Sitnica on gauging station Nedakovac.

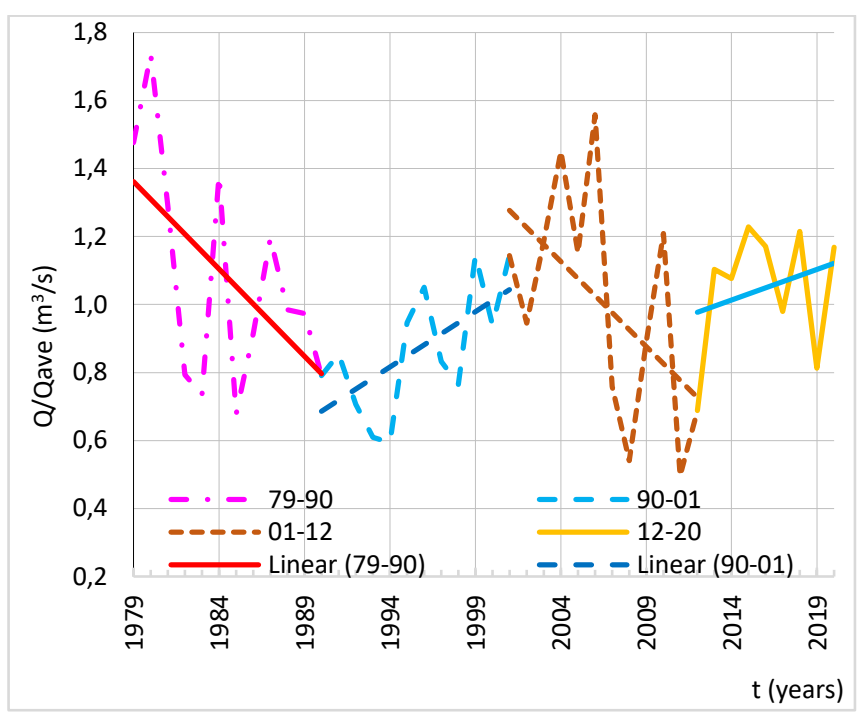

Fig. 13. Annual average flows and their trends - Subbasin of upper flow of Ibar River (mauntain and non-urbanised subbasin only solar activity impact, no human impact)

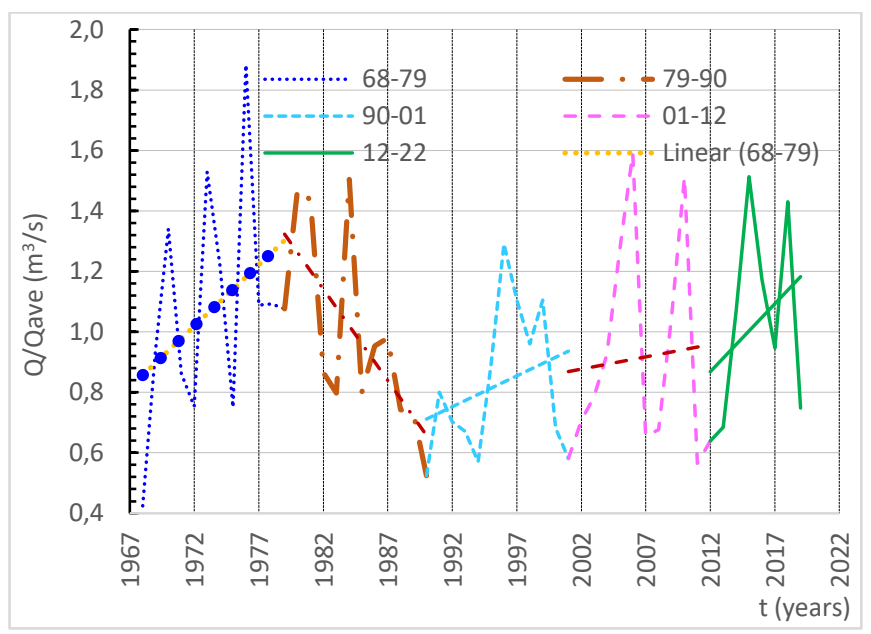

Fig. 14. Annual average flows and their trends - Basin of Sitnica River, as subbasin of Ibar River, (Low-land, urbanised, convection rainfall increment and fecalised river).

\section{RESULTS AND DISCUSSION}

1. First result is excellent correlation coefficient of daily average flows between non-observed river Sitnica at
Nedakovac and very good observed river Topljica at Doljevac $(\mathrm{R}=98 \%)$.

2. Second result is completion of few existing daily average flows data with simulated up-to-date data, which means completion of period 1963-2016.

3. Third result is identification of movement of long-term annual hydrographs, as well as their periodicity, homoscedasticity, and trends, for different time periods. These results are useful for estimation of water balances, droughts and floods.

Exactly, for river Sitnica after all, can be concluded as follows:

1) Flows during time period 1963-1990, were more periodic, more continual with soft variances and soft decrement trends of all time (daily and annual flows)

2) Flows during recent three decades 1990-2016, are distinguished with disturbed periodicity, extremized increment of variances and moderate trend increment of flows.

At the end, forecasting of next two decades, shows, further extremization, strong trend increments of precipitation and temperatures, and average increment of flows, perhaps due to solar activity and the earth reaction (increment of urbanization visa vegetation cover, which causes increment of convective rainfall visa frontal).

\section{CONCLUSION}

Urban area must respect proportion with vegetable ground cover, to avoid increment of convective rainfall and extrem distribution of river flows in time and space.

Urgent control of Global and Local heating, by reduction of fosil fuels, and by planting of trees.

\section{REFERENCE}

[1] Chong-Yu Xu, "Hydrologic Models", Uppsala University, Department of Earth Sciences, Hydrology, Uppsala, 2002.

[2] Enti Hidrometeorologjik I Prishtinës: " Reshjet mujore, Temperaturat dhe Lagështia mujore mesatare për Prishtinë Pejë dhe Ferizaj.

[3] J. Kirkby: "Cosmic rays and climate", CERN Colloquium, 4 June, 2009.

[4] N. Batinic, D. Jevtic D: "Kosovo Water Resources Plan, Book 1, Notebook 1, Clime", "Jaroslav Cerni" Institution, Belgrad, 1982.

[5] N. Batinic, D. Jevtic D: "Kosovo Water Resources Plan, Book 1, Notebook 2, Kosovo Surface Water Regime", "Jaroslav Cerni" Institution, Belgrad, 1983.

[6] N. Zivkovic, Lj. Gavrilovic, "O Rezimu Velikih Voda Reka Kosova I Metohije", Glasnik Srpskog Geografskog Drustva, Beograd, 2009.

[7] Pristina Hydrometeorological Institution: "Daily average flows of Sitnica river for years 1963-1986".

[8] Serbian Republican Hydro-meteorological Institution:" Hydrological Data Books for Serbia", 1990-1999 years, Belgrade.

[9] Yougoslavian Federal Hydrometeorological Institution: "Hydrological Annualy Data Book of Yougoslavia", years 1977, 1979, 1981, 1982 1983, 1986, Belgrade.

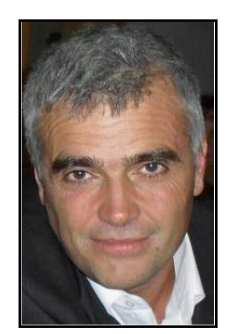

Arban Berisha born in Ferizaj on 26.9.1964. In 1989 he has graduated in Civil Engineering Faculty of Prishtina (Kosova), Department of Hydroengineering. Since 1992 he has been working in that faculty as Teaching Assistant, by the subjects of Hydrology, Hidraulics and Water Supply and Sewage.

He used to work on different water structures projects, river basin studies, he participated in many workshops and conferences, with national and international staff.

Prof. Berisha has translated for students, and local institutions all the time. 